\title{
EFFECTS OF PESTICIDES ON PHOTOSYNTHESIS OF MARINE PHYTOPLANKTON
}

\author{
NAHEED IKRAM* AND NAFISA ShOAIB \\ Centre of Excellence in Marine Biology, University of Karachi, Karachi-75270, Pakistan
}

Keywords: Pesticides, Marine phytoplankton, Photosynthesis

\begin{abstract}
Toxicity of pesticides, namely chlorpyrifos, malathion, cypermethrin, lambda-cyhalothrin and buctril were tested on the photosynthetic behavior of marine phytoplankton. The phytoplankton population was exposed to $0.01,0.03,0.06$ and $0.09 \mathrm{ppm}$ of test pesticides. The toxicity of pesticides stands in the order of lambda-cyhalothrin $>$ chlorpyrifos $>$ buctril $>$ malathion $>$ cypermethrin. The most toxic pesticide was lambda-cyhalothrin having $\mathrm{IC}_{50}$ value of $0.014 \mathrm{ppm}$. Toxicity of cypermethrin was less on phytoplankton compared to others.
\end{abstract}

Global use of agrochemicals in an increasing rate has led to the concern about their impact on ecosystems. Pesticides protect the economically important crops from pathogens but when their residues enter into the aquatic ecosystems, affect non targeted primary producers (Wang et al. 2011). Recently large number of pesticide components have been reported from fresh and marine ecosystems releasing toxic molecules (Chevre et al. 2006, Gilliom, 2007). Mixtures of pesticides are more toxic than individual pesticide.

Phytoplankton which forms the base of the marine food chain are affected by pesticide residues present in the contaminated sea water (Belden et al. 2007). Stevenson and Pan (1999) showed that diatoms being the major component of marine phytoplankton are harmed by the exposure of different pesticides and thus the balance of ecosystem disturbed. Diatoms are bioindicator of pesticides, several researchers demonstrated negative impact of pesticides on cell structure, metabolism and community composition of diatoms (Dorigo et al. 2004).

Among pesticides lambda-cyhalothrin affects macroinvertebrates, zooplankton and phytoplankton (Wijngaarden et al. 2006). Cypermethrin alter the community composition of phytoplankton, crustacean, rotifer and zooplankton (Rasch et al. 2003). In marine ecosystems, growth of Skeletonema costatum (Grev.) Cleve, Scrippsiella trochoidea (Stein) Loeblich and Chattonella marina (Subrahmanyan) Hara \& Chihara were inhibited after exposure to cypermethrin (Wang et al. 2010). Another pesticide chlorpyrifos affects metabolism of phytoplankton community (Shoaib et al. 2012). The present study aims to observe the impact of cypermethrin, lambda-cyhalothrin, chlorpyrifos, buctril and malathion on photosynthesis of phytoplankton in natural environment.

Samples of phytoplankton were collected from Sandspit $\left(24^{\circ} 50.141^{\prime} \mathrm{N}\right.$ and $\left.066^{\circ} 44.245^{\prime} \mathrm{E}\right)$ beach in Karachi, Pakistan. By using phytoplankton net (147 $\mu \mathrm{m}$ mesh Nitex brand nylon bolting cloth) towed for ten minutes in the surface water. The phytoplankton was identified on the basis of their characteristics (Tomas 1997).

Physiological parameters such as temperature, $\mathrm{pH}$ and salinity of water was determined. Water temperature: $24^{\circ} \mathrm{C}, \mathrm{pH}: 7.7$, salinity 36 (part per thousand). A set of triplicate light and dark bottles were used for control. Concentrations $(0.01,0.03,0.06$ and $0.09 \mathrm{ppm}$ ) of all the experimental pesticides as mentioned before were prepared in flasks and then was transferred into

*Author for correspondence: <naheed.ikram@yahoo.com>, <nafisashoaib@yahoo.com>. 
glass stoppered BOD bottles $(150 \mathrm{ml})$. A set of light bottles containing pesticides and phytoplankton were incubated under ambient light (sunlight) for three hours. Another similar set was incubated in a black box. A set of triplicate light and dark bottles were used for control. The gross production of the phytoplankton was measured by Strickland and Parsons (1968). With the help of $\log \log$ graph inhibitory concentration of pesticides $\left(\mathrm{IC}_{50}\right)$ were determined.

The results of the present work have been plotted in Fig. 1 which shows that chlorpyrifos, cypermethrin, lambda-cyhalothrin, malathion and buctril pesticides suppressed the photosynthetic percentage of phytoplankton. From Fig. 1 it is evident that increased concentration of pesticides causes suppression in the photosynthetic percentage of phytoplankton community. Among all the pesticides lambda-cyhalothrin showed maximum suppression in photosynthesis rate as compared

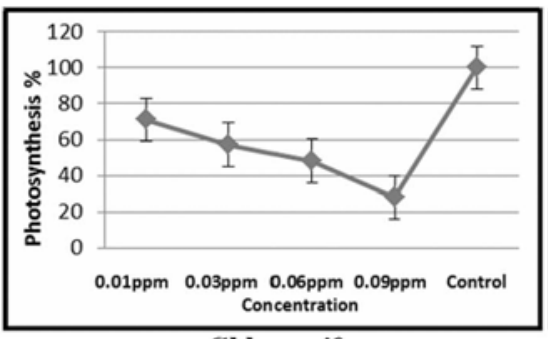

Chlorpyrifos

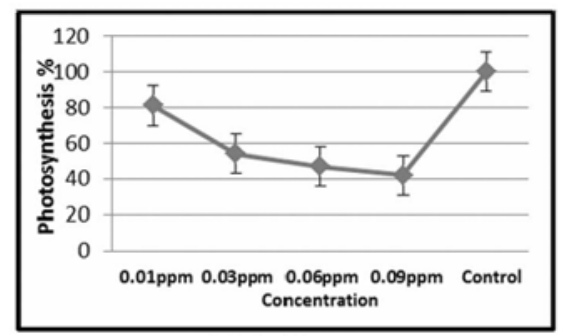

Malathion

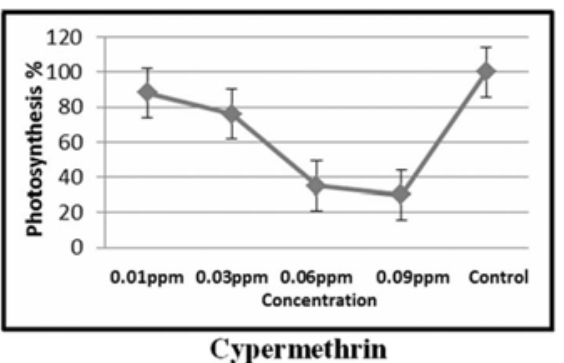

Cypermethrin

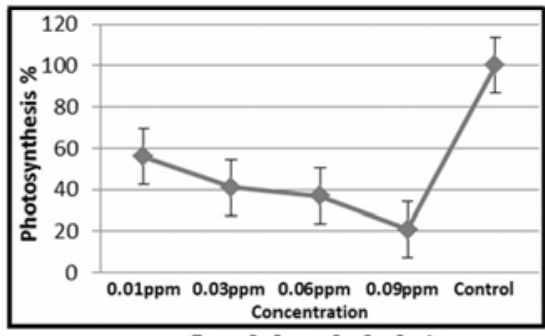

Lambda-cyhalothrin

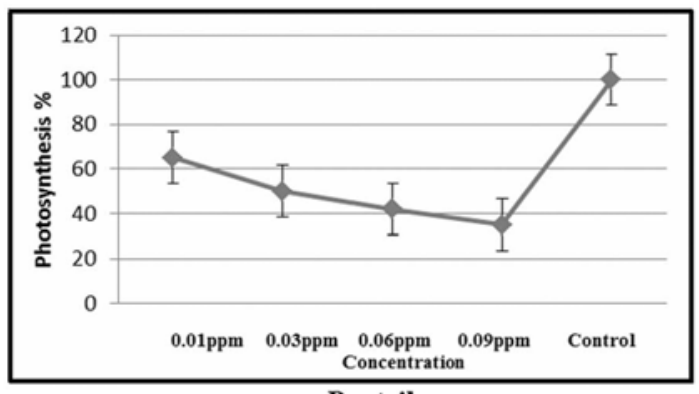

Buctril

Fig. 1 Effect of pesticides on the photosynthetic percentage of phytoplankton.

to other pesticides. The $\mathrm{IC}_{50}$ (inhibitory concentration) value of lambda-cyhalothrin is $0.014 \mathrm{ppm}$ which indicates the toxicity of this pesticide. The second toxic pesticide was chlorpyrifos having $\mathrm{IC}_{50}$ value of $0.028 \mathrm{ppm}$ following buctril having $\mathrm{IC}_{50}$ value of $0.030 \mathrm{ppm}$. Malathion stands fourth in toxicity having $\mathrm{IC}_{50}$ value of $0.043 \mathrm{ppm}$ and cypermethrin stands fifth in toxicity having $\mathrm{IC}_{50}$ value of $0.056 \mathrm{ppm}$ (Table 1). 
The inhibition of photosynthetic rate in the present study is in good agreement with some previous reports showing inhibitory effects of pesticides on phytoplankton (Delorenzo and Serrano 2003, Mohapatra et al. 2003). In the present study, lambda-cyhalothrin (synthetic pyrethroid) showed the highest degree of suppression in the percentage of photosynthetic rate of phytoplankton. Shoaib et al. (2011) reported that synthetic pyrethroid pesticide is most toxic to phytoplankton as compared to organophosphate pesticides.

Table 1. Effect of pesticides on photosynthesis of phytoplankton.

\begin{tabular}{lccc}
\hline Pesticides & $\mathrm{IC}_{50(\mathrm{ppm})}$ & $\mathrm{p}$-value & F-value \\
\hline Chlorpyrifos & 0.028 & 0.9768 & 0.0234 \\
Malathion & 0.043 & 0.9924 & 0.0076 \\
Lambda-cyhalothrin & 0.014 & 0.9878 & 0.0122 \\
Cypermethrin & 0.056 & 0.9893 & 0.0106 \\
Buctril & 0.030 & 0.9831 & 0.0169 \\
\hline
\end{tabular}

Berard et al. (2003) reported that triazine and atrazine herbicide showed ecotoxicological effects on communities of microalgae. According to Knauer et al. (2010) pesticides directly affect the D1 protein and photo system-II in photosynthesis. More specifically bensulfuron-methyl, butachlor and dimethoate affect PSII and PSI, showing inhibition in the photosynthetic rate and growth of cyanobacteria (Chen et al. 2007).

Phytoplankton community displayed a high level of variability in their sensitivity to different concentration of pesticides, which is a prerequisite for the restructuring of community patterns (Blanck 2002). The most toxic pesticide was lambda-cyhalothrin having $\mathrm{IC}_{50} 0.014 \mathrm{ppm}$ and in case of cypermethrin $\mathrm{IC}_{50}$ was $0.056 \mathrm{ppm}$. Rasch et al. (2003) reported that cypermethrin in 0.01 ppm showed alterations in the species composition of phytoplankton communities. Alteration of the species composition of the autotrophic communities caused indirectly by cypermethrin was observed by Lina et al. (2003). Results from cypermethrin pollution in sea waters may lead to a shift in phytoplankton community structure from diatom to harmful dinoflagellate species and potentially stimulate harmful algal blooms (Wang et al. 2011). The imbalance of a flora could favor species suppressed by other species, hence producing population explosions and dominance of the planktonic community by noxious groups. Interspecific variations may be due to the chemical composition of pesticides. Number and kinds of esters present in organophosphates and their stereochemistry, spectrum of activity, and toxicology (Reddy and Rao 1992).

The results of the present investigation provide knowledge about the ecotoxicological effects of pesticide stress on the phytoplankton. Chlorpyrifos showed negative impact on biovolume, growth and ultra structure of Ankistrodesmus gracilis (Asselborn et al. 2015). Mohapatra et al. (2003) investigated that chlorophyll a, carotenoids and phycobiliproteins significantly reduced when Anabaena doliolum Bhar exposed to cypermethrin. Photosynthetic organisms of marine ecosystem play an important key role in food chain on which majority of organisms depends. Phytoplankton are primary producers of marine ecosystem and if they are disturbed the whole food-web will be affected so there is a need to aware farmers and researchers to move towards some natural methods to control pest. 


\section{Acknowledgements}

The authors would like to thank Higher Education Commission, Islamabad, Pakistan for providing funds to carry out present research. The facility provided by Centre of Excellence in Marine Biology is well appreciated. The authors would like to thank Dr. Pirzada Jamal Ahmed Siddiqui, ex Director, Centre of Excellence in Marine Biology for his guidance and support.

\section{References}

Asselborn V, Fernández C Zalocar Y and Parodi ER 2015. Effects of chlorpyrifos on the growth and ultrastructure of green algae, Ankistrodesmus gracilis. Ecotoxicol Environ Saf. 120: 334-41.

Belden JB, Gilliom RJ, Martin JD and Lydy MJ 2007. Relative toxicity and occurrence patterns of pesticide mixtures in streams draining agricultural watersheds dominated by corn and soybean production. Integr. Environ Assess Manag. 3(1): 90-100.

Berard A, Dorigo U, Mercier I, Becker-van Slooten K, Grandjean D and Leboulanger C 2003. Comparison of the ecotoxicological impact of the triazines Irgarol 1051 and atrazine on microalgal cultures and natural microalgal communities in Lake Geneva. Chemosphere 53(8): 935-44.

Blanck H 2002. A Critical Review of Procedures and Approaches Used for Assessing Pollution-Induced Community Tolerance (PICT) in Biotic Communities. Human and Ecological Risk Assessment: An International Journal. 8(5): 1003-1034.

Chen Z, Juneau P and Baosheng Q 2007. Effects of three pesticides on the growth, photosynthesis and photoinhibition of the cyanobacterium. Aquatic Toxic. 81(3): 256-265.

Chevre N, Loepfe C, Singer H, Stamm C, Fenner K and Escher BI 2006. Including mixtures in the determination of water quality criteria for herbicides in surface water. Environ. Sci. Technol. 40: 426435.

Delorenzo ME and Serrano L 2003. Individual and mixture toxicity of three pesticides; atrazine, chlorpyrifos, and chlorothalonil to the marine phytoplankton species Dunaliella tertiolecta. J. Envi. Sci. Health. 38(5): 529-38.

Dorigo U, Bourrain X, Berard A and Leboulanger C 2004. Seasonal changes in the sensitivity of river microalgae to atrazine and isoproturon along a contamination gradient. Sci. Tot. Environ. 318(-3): 101114.

Gilliom RJ 2007. Pesticides in U.S., streams and groundwater. Environ. Sci. Tech. 41: 3407-3413.

Knauer K, Leimgruber A, Hommen U and Knauert S 2010. Co-tolerance of phytoplankton communities to photosynthesis II inhibitors. Aquatic Toxicology 96(4): 256-263.

Lina WR, Friberg-Jensen U, Per WLU and Christoffersen K 2003. Effects of the pyrethroid insecticide cypermethrin on a freshwater community studied under field conditions. II. Direct and indirect effects on the species composition. Aquatic Toxicology 63(4): 373-389.

Mohapatra PK, Patra S, Samantaray PK and Mohanty RC 2003. Effect of the Pyrethroid Insecticide Cypermethrin on Photosynthetic Pigments of the Cyanobacterium Anabaena Doliolum Bhar. Polish J. Env. Stu. 12 (2): 207-212.

Rasch LW, Jensen UF, Woin P and Christoffersen K 2003. Effects of the pyrethroid insecticide cypermethrin on fresh water community studied under field conditions. II.Direct and indirect effects on the species composition. Aquatic Toxicology 63: 373-389.

Reddy MS and Rao KV. 1992. Toxicity of selected insecticides to the penaeid prawn Metapenaeus monoceros (Fabricius). Bull. Environ. Contam. Toxi. 48: 622-629.

Shoaib N, Siddiqui PJA, Ali A, Burhan Z and Shafique S 2011. Toxicity of pesticides on photosynthesis of diatoms, Pak. J. Bot. 43(4): 2067-2069.

Shoaib N, Siddiqui PJA and Khalid H. 2012. Toxicity of Chlorpyrifos on some marine cyanobacteria species. Pak. J. Bot., 44(4): 1131-1133. 
Stevenson RJ and Pan Y 1999. Assessing environmental conditions in rivers and streams with diatoms. In: The diatoms - applications for the environmental and earth sciences. Cambridge University Press, Cambridge.

Strickland JDH and Parsons TR 1968. A manual of seawater analysis. Bulletin of Fisheries Research Board, Ottawa, Canada.

Tomas CR 1997. Identifying marine phytoplankton. Florida Department of Environmental Protection. Florida Marine Research Institute. Florida. pp. 240-281.

Wang ZH, Nie XP and Yue WJ 2011. Toxicological effects of cypermethrin to marine phytoplankton in a coculture system under laboratory conditions. Ecotoxicology 20(6): 1258-67.

Wang ZH, Yang Y, Yue W, Kang W, Liang W and Wei L 2010. The growth behavior of three marine phytoplankton species in the presence of commercial cypermethrin. Ecotoxicology and Environmental Safety 73(6): 1408-1414.

Wijngaarden RP, Brock TC, Brink PJ, Gylstra R and Maund SJ 2006. Ecological effects of spring and late summer applications of lambda-cyhalothrin on freshwater microcosms. Arch. Environ. Contam. Toxicol. 50(2): 220-39. 